Research Report No. 45/2009

\title{
Reconstructing the WTO Legitimacy Debates Towards Notions of Development
}

Michael Fakhri

Follow this and additional works at: http://digitalcommons.osgoode.yorku.ca/clpe

\section{Recommended Citation}

Fakhri, Michael, "Reconstructing the WTO Legitimacy Debates Towards Notions of Development" (2009). Comparative Research in Law of Political Economy. Research Paper No. 45/2009.

http://digitalcommons.osgoode.yorku.ca/clpe/311 


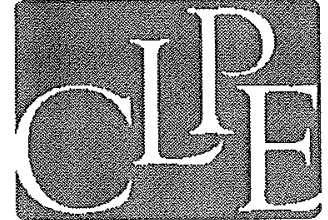

\section{Comparative Research in Law \& Political Economy}

Michael Fakhri

Reconstructing the WTO Legitimacy Debates Towards Notions of Development

EDITORS: Peer Zumbansen (Osgoode Hall Law School, Toronto, Director, Comparative Research in Law and Political Economy, York University), John W. Cioffi (University of California at Riverside), Nassim Nasser (Osgoode Hall Law School, Toronto, Production Editor) 


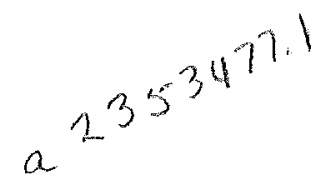

Electronic copy available at: http://ssrn.com/abstract=1500562 
CLPE Research Paper 45/2009

Vol. 05 No. 08 (2009)

\title{
Michael Fakhri
}

\section{Reconstructing the WTO Legitimacy Debates ToWards Notions of DEVELOPMENT}

\begin{abstract}
This paper explicates competing conceptions of the WTO by examining the relationship between the perceived legitimacy crisis of the WTO and the emergence of development onto the global trade agenda. The general argument is that the WTO legitimacy debate in trade law literature can be understood as a proxy for a development debate. By reconstruing the legitimacy debate as a development debate, this paper shows how implicit within legitimacy arguments are competing conceptions of the WTO's function and purpose and that these conceptions are embedded within a broader development framework.

The unfortunate effect of the contestations and justifications of the WTO's legitimacy has been the obscuring of normative assumptions underpinning conceptions of the WTO. One suspects that the more the discourse continues in this tug-of-war of legitimacy, the more entangled our understanding of the WTO will be. Gaining a better sense of what conceptions of the WTO are dominating legal thought allows for a more substantive and detailed debate as to what the function and purpose of the WTO should be.
\end{abstract}

Keywords: WTO, legitimacy, Constitutionalization, Institutional functionalism

JEL člassification: B25, F02, O19, K33

\author{
Michael Fakhri \\ S.J.D. Candidate (University of Toronto), \\ LL.M. (Harvard), LL.B. (Queen's), \\ B.Sc. (Western).
}




\title{
Reconstructing the WTO Legitimacy Debates Towards Notions of Development
}

\author{
Michael Fakhri*
}

\section{INTRODUCTION}

During a World Trade Organization (WTO) Ministerial Conference in Seattle, December 1999, thousands of protestors took to the streets to voice vehement disapproval against the trade institution. Some commentators criticized them for having a rowdy, incoherent agenda and little understanding of the WTO. Despite this criticism, many trade law scholars referenced these protests as the moment that exemplified the questioning of the WTO's legitimacy.' Legal literature usually assumes that the WTO's legitimacy has been severely challenged and asks: how can we make the WTO more legitimate?

The Ministerial conference that failed to commence in Seattle, restarted in 2001 in Doha with what was dubbed by Member State negotiators and policy-makers as the "Development Round". The Doha Development Round is part of a call not only by WTO Member States but also by individuals and groups alike to make the WTO an institution for development and to ensure that world trade is a means for development. How this is to be done is a deeply contested issue evidenced by the stalled Doha Round negotiations and recent scholarly exploration. ${ }^{2}$

This paper explores the relationship between these two events of the last decade: the perceived legitimacy crisis of the WTO and the emergence of development onto the global trade agenda. ${ }^{3}$ My general argument is that the WTO legitimacy debate in trade law literature can be understood as a proxy for a development debate. By reconstruing the legitimacy debate as a development debate, I show how implicit within legitimacy arguments are competing conceptions of the WTO's function and purpose and that these conceptions are embedded within a broader development framework.

\footnotetext{
* S.J.D. Candidate (University of Toronto), LL.M. (Harvard), LL.B. (Queen's), B.Sc. (Western). An earlier version of this paper was presented at the American Society of International Law, Biennial International Economic Law Interest Group Conference, 14 November 2008, Washington D.C., USA and the Critical Legal Conference, 12 September 2009, University of Leicester, UK. I wish to thank Kerry Rittich, Michael Trebilcock, J. Patrick Kelly, Riddhi Dasgupta, Morag Goodwin, Andrew Lang and Ronnie R. F. Yearwood for their comments on earlier drafts. I am also indebted to B.S. Chimni and Frank Garcia for their encouragement. All errors are mine.

'See for e.g. Michael Trebilcock, "Critiquing the Critics of Economic Globalization" (2005) 1 J. Int'l L. Int'l Rel. 213.

${ }^{2}$ See for e.g. Andrew Charlton \& Joseph Stiglitz, Fair Trade For All: How Trade Can Promote Development, rev. ed. (2007); Roberto Mangabeira Unger, Free Trade Reimagined: The World Division of Labor and the Method of Economics (2007); and Dani Rodrik, One Economics, Many Recipes: Globalization, Institutions, and Economic Growth (2007).

${ }^{3}$ Cf. Tomer Broude, "The Rule(s) of Trade and the Rhetos of Development: Reflection on the Functional and Aspirational Legitimacy of the WTO" (2006) 45 Columb. J. Tranat'l L. 221.
} 
The premise of this paper is that before we continue to engage in the necessary discussion of how to examine the WTO's effects upon marginalized communities ${ }^{4}$ and how to reconfigure the WTO in order to "reclaim" development in the world trading system, ${ }^{5}$ we must better understand what development frameworks already prevail within current debates.

This paper also responds to the broader concern regarding the dearth of examinations of international institutions that are at once legal, theoretical, and descriptive. ${ }^{6}$ The WTO debate, much like debates regarding international institutions in general, thus far has been primarily prescriptive. ${ }^{7}$ That is to say, jurists have focused on arguing as to what conditions are necessary to enhance the WTO's legitimacy. This stems from the assumption that the WTO as a project is a good thing and therefore its legitimacy must be improved. This paper, however, is a descriptive assessment of the legitimacy debate. It examines why commentators call for certain WTO reforms. Because very little descriptive work has been done regarding the WTO legitimacy debate, this paper is a sketch of the beginnings of what a larger descriptive project may entail. Admittedly, this paper is ambitious in its scope but modest in its proposal.

My primary purpose is to intervene into the debate in order to encourage a sharper, more defined discourse by suggesting that instead of simply defending the WTO, commentators should be clearer as to what is their conception of the WTO and explain why their conception is accurate and/or meritorious. This papers shows that examining the WTO only through the prescriptive lens of legitimacy obscures exactly what people are "for" or "against" in debates regarding the WTO. Thus, this paper looks to provide the tools to answer the question, "What conception of the WTO is being defended?"

The divisions between arguments in the legitimacy debate are usually understood to be between rule-based constitutionalization versus economic rights constitutionalization, sympathy versus skepticism regarding non-governmental participation, and support for a more legalized disputesettlement system versus a more politicized dispute-settlement system. By reconstruing the legitimacy debate as a development debate, I first show how constitutional discourse is a way of arguing for the primacy of markets or international institutions over the state, dispute settlement debates are negotiating the relationship between the WTO and the state, and participation and transparency arguments stem from a concern for the role of the state in global governance. Second, I show how the binaries in the legitimacy debate are not as stable as originally thought.

\footnotetext{
${ }^{4}$ B.S. Chimi, "The World Trade Organization, Democracy and Development: A View From the South" (2006) 40 J. World Trade 5

${ }^{5}$ Yong-Shik Lee, Reclaiming Development in the World Trading System (Cambridge: Cambridge University Press, 2006); Asif H. Qureshi, "International Trade for Development: The WTO as a Development Institution?" (2009) 43 J. World Trade 173.

${ }^{6}$ Jan Klabbers, An Introduction to International Institutional Law, 2nd ed. (2009) at 32-35; José E. Alvarez, International Organizations as Law-makers (2005) at 586.

7 Jens Steffek, "The Legitimation of International Governance: A Discourse Approach" (2003) 9 Eur. J. Int'l Rel. 249.
} 
What at first seem to be incongruent positions appear to be more related. Likewise, certain positions that at first blush appear to be similar, are revealed to arise from different conceptions of the WTO's function and purpose. What is ultimately revealed is that different conceptions of the WTO do not necessarily predicate a particular normative vision - how a specific conception of the WTO associates with a particular normative development framework depends which aspect of the WTO's legitimacy is being debated.

I detail what I mean by reconstruing the legitimacy debate as a development debate and the limits of a "legitimacy" discourse in Part II. I then examine three forms of the legitimacy debate: constitutionalization (Part III), dispute settlement (Part IV), and participation and transparency (Part V). Part VI concludes.

\section{RECONSTRUING THE LEGITIMACY DEBATE TOWARDS DEVELOPMENT}

The debate surrounding the WTO is often framed as questioning whether the current operation of the WTO makes it a legitimate international institution. Scholars will usually enter the debate informed by a pre-existing conceptual construction of the WTO's function and purpose. The pattern of the debate is often that the WTO is assumed to institutionalize a particular notion of trade, then it is argued that the WTO should be changed in order to better adhere to this notion of trade or it is criticized for prioritizing trade as a value to the exclusion of other values. The preconception of the WTO is thereby reinforced through the way the WTO is examined. ${ }^{8}$ Preconceptions of the function and purpose of the WTO and legitimacy not only affect the analytical framework in which the WTO is examined, but also shape policymaking within the WTO's institutional and bureaucratic structure.

The problem, however, is that allowing legitimacy criteria to affect descriptive understandings of the WTO makes it difficult to establish what actually is the function of the WTO and argue what it should be. Rather than exploring the structure and effects of the WTO, questions regarding the WTO are framed within preconceived notions of legitimacy of what the WTO should be doing. In this paper, I flip the orthodox approach on its head and examine the legitimacy debate to

\footnotetext{
${ }^{8}$ Patricia Nanz, "Democratic Legitimacy and Constitutionalisation of Transnational Trade Governance: A View from Political Theory", in Christian Joerges \& E-U Petersmann, eds., Constitutionalism, Multilateral Trade Governance and Social Regulation (2006) 59 at 62.

${ }^{9}$ See for e.g. Peter Sutherland et al., The Future of the WTO: Addressing Institutional Challenges In The New Millennium (Geneva: WTO, 2004), online: <http://www.wto.org/english/thewto_e/10anniv_e/future_wto_e.htm> (the "Sutherland Report"). Cf. Joseph Weiler, "The Rule of Lawyers and the Ethos of Diplomats: Reflections on the Internal and External Legitimacy of Dispute Settlement", in Roger B. Porter et al., Efficiency, Equity, And Legitimacy: The Multilateral Trading System At The Millennium (2001) 334.
} 
understand the different pre-existing conceptual constructions of the WTO. A close reading of the literature using this approach presents the WTO legitimacy debate as a development debate. To reconstrue the debates regarding legitimacy towards development, we can consider the WTO legitimacy debate to be between different styles of functionalism. Functionalism, especially in discussions of law and development, administrative law and governance, focuses on the purpose that legal institutions serve and the objects of regulation in economic and political life. ${ }^{10}$ In fact, functionalism has dominated how international institutions in general are examined. ${ }^{11}$ When debating the WTO's legitimacy, differences arise through varied conceptions of the WTO's function and purpose and objects of regulation in global economic and political life.

Broadly, there are two approaches to conceiving the function and purpose of the WTO that inform the legitimacy debate. What I call the economic functionalist approach focuses on the economic benefits of the WTO. This approach suggests that the WTO's legitimacy is increased the more the WTO's structure and resulting state action best reflect a particular trade theory. The assumption is that the purpose of the WTO is to discipline countries to liberalize trade by lowering tariffs, quotas, and so-called non-tariff barriers, which efficiently generates welfare. The different forms of welfare generated by liberal trade considered include increases in economic growth, market competition, and/or personal liberty. The more the WTO reflects the appropriate theory, the more opportunity there will be for increased welfare (however defined), thereby increasing the WTO's legitimacy. The other conception of the WTO, what I call the institutional functionalist approach, usually takes for granted that free trade generates welfare gains and focuses on improving technical and policy cooperation between Member States within the WTO by making the rules clearer and more coherent. The WTO's legitimacy is increased by improving the WTO's internal regulatory coherence and/or by aligning the WTO regulations with other norms of international law.

I will show how each conception is implicitly embedded within a development framework. By development I mean prescriptions as to how to change social, economic, and political structures to advance a community's welfare (however defined). ${ }^{12}$ And by development framework I mean a prescribed role and relationship amongst of the state, market, law, international institutions and non-governmental actors. Outlining what substantive details of a development framework are associated with each conception of the WTO provides a sharper account of what is at stake in the legitimacy debates.

Since I have presented the different conceptions as a stylized representation, and for the sake of space, I do not provide exhaustive references to all relevant texts. Showing the limitations and

\footnotetext{
${ }^{10}$ Kerry Rittich, "Functionalism And Formalism: Their Latest Incarnations In Contemporary Development And Governance Debates" (2005) 25 U.T.L.J. 853 at 855. See also Peer Zumbansen, "Law after the Welfare State: Formalism, Functionalism and the Ironic Turn of Reflexive Law" (2008) 56 Amer. J. Comp. L. 769.

${ }^{11}$ Alvarez, supra note 6 at 17-29.

${ }^{12}$ I draw my definition of development from Gunnar Myrdal, " 'Growth' and 'Development”, in Gunnar Myrdal, Against the Stream: Critical Essays on Economics (1973) 182.
} 
tensions of economic and institutional functionalist arguments is not intended to be a critical fait accompli, but rather it is a way to craft analytical tools that can start a sharper development debate with a clearer understanding of the function and purpose of the WTO. ${ }^{13}$

\section{Constitutionalization}

\section{A. INTRODUCTION}

The WTO is commonly used as an example of the constitutionalization of international law. I focus on the works of John H. Jackson and Ernst-Ulrich Petersmann as two influential exemplars of different conceptions of constitutionalization and the WTO. Jackson considers the "constitution" of international trade law to mean the institutional reflection of however the world trading system actually operates in practice. The world trade constitution is whatever emerges from international trade institutions and as such, WTO law embodies the current trade constitution. To Petersmann, free trade enhances individual autonomy and liberty by freeing economic activity and protecting individual action from government interference. Free trade is considered to be a human right of utmost priority. Accordingly, since the WTO embodies this dedication to free trade, it represents the global constitutional notion of the right to trade.

The critiques of constitutional discourse with respect to the WTO and trade has been that it is a discourse that privileges specific notions of legal forms such as judicial norm-generation, ${ }^{14}$ that it prioritizes economic freedom over political freedom, ${ }^{15}$ and that it takes for granted the social and economic benefits of liberalized trade. ${ }^{16}$ The debate has involved answering the questions: is the WTO constitutionalizing? And if so, should the WTO be constitutionalizing? Deborah Cass has argued that this is an extremely restrictive question because it reifies the WTO as something that someone is either for or against and that:

[i]t says that it is not possible to answer 'is-or-is-not', or 'should-or-should-not' question because the very terms of the discussion already presuppose the existence of the

\footnotetext{
${ }^{13}$ In this paper, I leave it open as to the merits of a functionalist approach. I implicitly eschew functionalism in Michael Fakhri, "Law as the Interplay of Ideas, Institutions, and Interests: Using Polanyi (and Foucault) to Ask TWAIL Questions" (2008) 10:4 Int'l Community L. Rev. 455.

${ }^{14}$ Ruth Buchanan, "Legitimating Global Trade Governance: Constitutional And Legal Pluralist Approaches" (2006) 57 Northern Ireland Legal Quarterly 654 at 662

${ }^{15}$ Robert Howse and Kalypso Nicolaidis, "Enhancing WTO Legitimacy: Constitutionalization or Global Subsidiarity?" (2003) 16 Governance 73 at 74.

${ }^{16}$ Deborah Cass, The Constitutionalization of the World Trade Organization: Legitimacy, Democracy, and Community in the International Trading System (2005) at 69.
} 
phenomenon. This makes it virtually impossible to escape from the terms of the assumption in order to try to answer the constitutionalizing question. ${ }^{17}$

When reconstrued as a development debate, Jackson's arguments present an institutional functionalist understanding of the WTO, whereas Petersmann presents an economic functionalist version. With these insights we can follow Cass's suggestion to consider the development implications of constitutional models in terms of distribution of wealth and power. ${ }^{18}$

\section{B. INSTITUTIONAL FUNCTIONALISM}

\section{The Constitutional Debate}

Jackson, was one of the first (if not the first) to use the term "constitution" when discussing the international economic system. ${ }^{19}$ In recent scholarship, Jackson has explained that he uses "constitution" as a moniker describing the institutional structure of the "world trading system" as whatever norms and practice emerge from international trade institutions; the concept of the constitution is flexible and adaptable to the changes in the international trade institution. ${ }^{20}$ Jackson's concept of constitutionalization can be summarized as such:

- The trade "constitution" is composed of a complex mix of economic and governmental policies, political constraints and legal norms.

- The "constitutional" constraints that the legal norms generate may frustrate decisionmakers and economists, but they are necessary to manage competing policy goals in an interdependent world.

- The rule-oriented structure of the WTO is its greatest strength for it creates a predictable system, allows for redressing unfair power imbalances between nations, and prevents escalating international tensions.

To Jackson, the WTO functions as an international system of predictable and stable rules intended to overcome politics and government short-sightedness. The "constitutional structure"

\footnotetext{
${ }^{17} \mathrm{Ibid}$. at 208 .

${ }^{18} \mathrm{Ibid}$. at 242.

${ }^{19}$ In this section I draw from the following work of John Jackson: World Trade and the Law of GATT (1969); The World Trading System: Law and Policy of International Relations, $2^{\text {nd }}$ ed. (1997); The World Trade Organization: Constitution and Jurisprudence (1998); "The WTO 'Constitution' and Proposed Reforms: Seven Mantras Revisited" (2001) 4 J, of Int'1 Econ. L. 67; Sovereignty, the WTO and Changing Fundamentals of International Law (2006); "International Economic Law in Times That Are Interesting" (2000) 3 J. of Int'l Econ. L. 3; "Fragmentation or Unification Among International Institutions: The World Trade Organization" (1999) 31 N.Y.U. J. Int'l L. \& Pol. 823.

${ }^{20}$ Seven Mantras, ibid. at 70-71; Changing Fundamentals, ibid. at 49-53, 55.
} 
of world trade is composed of the international treaties, national institutions, and compliance with results of dispute resolution. International treaties are the paramount component of this constitutional structure. Over time, Jackson shifted in his scholarship from talking about the different laws that make up the world trade system constitution to talking about the "WTO constitution" implying that the world trade constitution primarily consists of the WTO. ${ }^{21}$

Cass has argued this institutional functionalist approach generated an assumed legitimacy and authority in regards to the WTO. ${ }^{22}$ The assumptions stemmed from international economic law scholars taking for granted the benefits of liberalized trade and the ability of international economic law to increase economic welfare. ${ }^{23}$ Cass suggests the expansion of the WTO's scope and functions beyond those of the GATT led legal scholars to conflate concepts of institutions and constitutions. ${ }^{24}$ The literature, with Jackson as the primary proponent, had a sense that a new Grundnorm was emerging because the new system possessed a unity and coherence associated with the development of a new legal order. This conflation was furthered by the desire to distinguish the old GATT system from the WTO due to the perception that the WTO was remarkably different than the GATT. So, the GATT was described as an institution whereas the WTO was a constitution. Once the WTO was conceived as a constitution, legitimacy (a core element of constitutionalization) emerged as a primary focus. Influenced by scholarship on "globalization", the lines between economic, political, and legal authority blurred making it seem plausible that the WTO is a political-legal constitution. The popular protests against the WTO, which are a paramount moment that enhanced the discussion of legitimacy with regards to the WTO, very likely furthered the use of constitutional discourse and its preoccupation with legitimacy. ${ }^{25}$

\section{The Contours of a DeVelopment Framework}

To begin to gain a clearer understanding of Jackson's development framework, I examine hîs use of the term "globalization" and its relationship with his conception of the function and purpose of the WTO. Jackson considers "globalization" as an inevitable force that has arrived. He acknowledges the ambiguity of the term "globalization" and states that it denotes the interdependence generated by developments since World War II in technology, communication,

\footnotetext{
${ }^{21}$ The World Trade Organization: Constitution And Jurisprudence, supra note 19 at 103. For an evolution of the use of "constitution" compare John H. Jackson, The World Trading System, 1st ed. (1991) at 299-301 and The World Trading System, 2d. ed. (1997), supra note 19 at 339-341.

${ }^{22}$ Cass, supra note 16 at 64

${ }^{23}$ Cass notes economic benefits of liberalized trade were assumed despite challenges to international economic law from scholars employing third-world approaches to international law, ibid. at 78-79.

${ }^{24}$ Ibid. at $28-59$.

${ }^{25}$ Ibid. at 63 .
} 
and transportation that effectively integrate all markets into a global market. ${ }^{26}$ There is, however, in Jackson's conceptual framework a tension between "globalization" and the WTO. It is not clear whether the WTO's purpose is to manage institutional and cultural difference as a response to globalization or whether the WTO's purpose is to affect domestic countries and institutions in order to generate globalization. ${ }^{27}$ Of course, these purposes are not mutually exclusive. But the result of leaving the WTO's role in globalization unclear is that presents the WTO as both inevitable and desirable. This is problematic because makes it difficult to identify the legal structures that affect or construct global markets.

This problem is pertinent within Jackson's framework given that he considers the legal structure of the WTO as central to the global economy. Jackson lauds the WTO as an exemplar of the rules-based approach that avoids power imbalances between nations and the influences of domestic politics. ${ }^{28}$ According to Jackson, the rule-based approach allows for the WTO to manage power between nations, achieve "optimal" government response, help national legislatures avoid being beheld by a specific set of constituents, and overcome actors in national executive bodies making decisions driven by their own personal goals. The power-based approach is avoided because the WTO refers to agreed rules to settle disputes instead of resorting to negotiations. ${ }^{29}$

To Jackson, the WTO's rule-based system is structured by law which implements an economic ideal. Jackson suggests we must understand that the primary principle of the WTO rules has to do with economic affairs. ${ }^{30} \mathrm{He}$ looks for guidance on how to manage the global economy by referencing economists that consider the market to be a paramount social institution. ${ }^{31}$ Jackson relies on economic theories that dictate that the international economic system should embody the idea of "liberal trade", which is defined as the trade policy whose "goal is to minimize the amount of interference of governments in trade flows that cross national borders." 32

Jackson acknowledges that "economists instruct us, that there both winners and losers in this process [of reducing trade barriers]. The basic concept of decades ago was that the advantages create a rising tide that lifts all boats. We now realize that not all boats are lifted, for one reason or another." 33 To Jackson, however, liberal trade theory leaves the issue of distribution unanswered because it is a political or "non-economic" matter. Accordingly, any detrimental

\footnotetext{
${ }^{26}$ The World Trading System, supra note 19 at 5-7.

${ }^{27}$ Compare for e.g. Changing Fundamentals, ibid. at 122; and Constitution and Jurisprudence, supra note 19 at 103.

${ }^{28}$ Constitution and Jurisprudence, supra note 19 at 89 :

${ }^{29}$ The World Trading System, supra note 19 at 350- 351; and "Times That Are Interesting", supra note 19 at 5.

30 "Fragmentation", supra note 19 at 824.

${ }^{31}$ See for e.g. "Fragmentation", ibid. at 825; Seven Mantras, supra note 19 at 69-70.

${ }^{32}$ The World Trading System, supra note 19 at 11.

33 "Seven Mantras", supra note 19 at 69. Seer also The World Trading System, supra note 19 at 20.
} 
domestic effects caused by the international trade system are to be addressed domestically and not by re-examining the international structures that may be causing these detriments.

Domestic transformations created by international legal effect will create "losers" who are at times, according to Jackson, driven by irrationality or emotion. ${ }^{34}$ When outlining that there are winners and losers that emerge from a liberal trade policy, Jackson considers that losses will be ameliorated through domestic "safeguards" and "adjustment" - despite not being too confident as to how economically or politically effective "safeguards" and "adjustments" are. ${ }^{35}$ All this suggests that international trade law should primarily focus on regulating the market and not on distributive effects. ${ }^{36}$

Moreover, according this view, international economic law should also consider whether "the nimble, well managed multinational corporations find their effective power enhanced by these international economic trends, ${ }^{, 37}$ implying that corporate actors are to be privileged to bring about intended socio-economic changes. Where Jackson looks to corporations to support normative economic change, he has an inherent mistrust of government's role in the market. The described role of international economic law is to limit what governments can do with respect to border measures and "non-tariff barriers" affecting trade. This desire to limit government's role stems from the assumption that countries inevitably act as rational actors who seek to maximize their own welfare without regard to other countries, and that national legislatures are usually beholden to particular constituents or government actors strictly driven by personal interest. ${ }^{38}$

Jackson assumes that governments, in order to enact the best economic policy, need the help of the WTO to overcome constraints of domestic politics and personal interests. But he does have faith in government's ability to devise the appropriate "rule-based" system for international cooperation. ${ }^{39}$ By emphasizing that international economic law is primarily about treaties and that the WTO (created by international treaty) is the primary international economic legal institution, Jackson shows some deference to national governments. ${ }^{40}$ Within this framework, - however, it is not clear as to why national governments are inherently mistrusted to "manage domestic economies and trade policies, but trusted to negotiate treaties and create international institutions. Also, Jackson notes that a liberal trade regime creates losses that can materially and emotionally affect people. Jackson leaves it to domestic politics to address these losses. This

\footnotetext{
${ }^{34}$ The World Trading System, ibid. at 24; "Seven Mantras", supra 19 at 69.

${ }^{35}$ The World Trading System, ibid. at 174-179; and 199-200.

${ }^{36}$ See Changing Fundamentals, at 86-87; The World Trade Organization: Constitution and Jurisprudence, at 101102; and "Seven Mantras" at 70, all supra note 19.

${ }^{37}$ The World Trading System, supra note 19 at 24.

${ }^{38}$ The World Trading System, ibid. at 350- 351; "Fragmentation", supra note 19 at 825; "Times That Are Interesting", supra note 19 at 5.

${ }^{39}$ The World Trading System, ibid. at 122.

${ }^{40} \mathrm{Ibid}$. at 122.
} 
begs the question of why are national governments left to ameliorate the detrimental affects of a liberal trade regime if there is an assumption that governments cannot be expected to act in the broader interests of the nation. 


\section{ECONOMIC FUNCTIONALISM}

\section{The Constitutional Debate}

The most vigorous and contested ${ }^{41}$ proponent of imagining the WTO as a constitution has been Ernst-Ulrich Petersmann. He considers trade to be a human right and the WTO a human rights constitution. ${ }^{42}$ Petersmann's concept of constitutionalization can be summarized as such:

- There are universal and inalienable human rights reflected by the fact that more than 100 international treaties and UN resolutions reaffirm these rights. ${ }^{43}$

- "Human rights" include liberty, non-discrimination, rule of law, social welfare, freedom of information, freedom of the press, property rights, and freedom of contract. ${ }^{44}$

- These human rights protecting individual autonomy and liberty constitute a "freedom of trade". ${ }^{45}$

- The WTO embodies an international dedication to this freedom of trade. ${ }^{46}$

- Therefore, (drawing from the EU experience) to ensure the WTO's legitimacy, the WTO must be interpreted within the broader human rights context and be considered as a constitution (the "world trade constitution") amongst the other international constitutions, and domestic constitutions (what he calls "multilevel constitutionalism"). ${ }^{47}$

\footnotetext{
${ }^{41}$ See for e.g. Robert Howse, "Human Rights, International Economic Law and Constitutional Justice: A Reply" (2008) 19 EJIL 945; and Ernst-Ulrich Petersmann, "Human Rights, International Economic Law and Constitutional Justice: A Rejoinder" (2008) 19 EJIL 955.

${ }^{42}$ In this section I draw on the more recent writing of Emst-Ulrich Petersmann: "Time for A United Nations 'Global Compact' for Integrating Human Rights into the Law of Worldwide Organizations: Lessons from European Integration" (2002) 13 E.J.I.L. 621; "The 'Human Rights Approach' Advocated by the UN High Commissioner for Human Rights and by the International Labour Organization: Is It Relevant for WTO Law and Policy?", in ErnstUlrich Petersmann, ed. Reforming The World Trade System: Legitimacy, Efficiency, and Democratic Governance (2005); "Multilevel Trade Governance in the WTO Requires Multilevel Constitutionalism", in Christian Joerges \& Ernst-Ulrich Petersmann, eds., Constitutionalism, Multilevel Trade Governance and Social Regulation (2006).

${ }^{43}$ See "Human Rights Approach", ibid.

${ }^{44}$ See "Integrating Human Rights", supra note 42 at 622, 627; and "Human Rights Approach", ibid. at 359.

${ }^{45}$ See "Multilevel Constitutionalism", stupra note 42 at 33 and 45.

${ }^{46}$ This is implicit in Petersmann's arguments. See for e.g. "Human Rights Approach", supra note 42 at 374-376 (arguing that 1994 Agreement establishing the WTO provides that it is intended, amongst other things, to protect individual freedom, non-discrimination, and rule of law).

${ }^{47}$ See "Multilevel Constitutionalism", supra note 42. Similarly, see John O. McGinnis \& Mark L. Movesian, "The World Trade Constitution" (2001) 114 Harv. L. Rev. 511 (makes similar economic arguments as Petersmann but draws from US constitutional discourse).
} 
The general normative critique is that Petersmann prioritizes economic liberty and attempts to ossify this via constitutional discourse. ${ }^{48}$ The human rights critique against Petersmann is that his understanding of human rights is a particular one yet it is presented as universal. ${ }^{49}$ Petersmann draws his definition of human rights primarily from Adam Smith, Immanuel Kant, and Friedrich Hayek in a manner that assumes that these thinkers form a coherent theory of human rights, that this theory is unquestionable, and that any disagreement is inaccurate. He has also been critiqued for buttressing his argument by presenting as a "fact" that international human rights, as reflected in the plethora of treaties, support his vision, ignoring the high level of contestation (politically, diplomatically, academically) within human rights discourse of the relationship between economic, social, civil and political rights thereby privileging economic liberty. ${ }^{50}$ Furthermore, Petersmann ignores one of the core debates in human rights discourse regarding its universal characteristic. He assumes that human rights are universal and necessarily normatively good and that his vision of rights is the inevitable one. ${ }^{51}$

The methodological critique of Petersmann is that he slips between a normative and descriptive argument and is vague in his terminology. Petersmann is arguing at the same time that the WTO should be constitutionalized in order to further the freedom of trade and that it is constitutionalizing already and therefore must be interpreted within the context of human rights.

\section{The Contours of a Development Framework}

What is rarely examined within this intense debate is the theory of development underlying this particular constitutional vision. Petersmann considers the WTO to be the embodiment of ideal values and therefore looks to further legitimize the trade institutions through constitutional and human rights discourse. His priority is to enhance individual liberty and autonomy. Accordingly, the market is thought to be the ideal mechanism to achieve this liberty. Petersmann considers the WTO to be an institution that structures the global market. Therefore, he wants to protect and further strengthen the WTO's power and prominence against governments captured by groups

\footnotetext{
${ }^{48}$ Howse and Nicolaidis stupra note 15; and Robert Howse, (2002) "Human Rights in he WTO: Whose Rights, What Humanity? Comment on Petersmann" (2002) 13 EJIL 651.

${ }^{49}$ See Philip Alston, "Resisting Merger and Acquisition of Human Rights by Trade Law: A Reply to Petersmann" (2002) 13 EJIL 815.

${ }^{50}$ Ibid.

${ }^{51}$ One debate in human rights that regularly reoccurs revolves around questioning whether there is, can be, or should be a universal human rights. Current human rights discourse has taken a turn towards the reflexive. See for e.g. Brooke Ackerly, Universal Human Rights in a World of Difference (2008); David Kennedy, The Dark Side of Virtue: Reassessing International Humanitarianism (2004); Makau Mutua, "Savages, Victims, and Saviors: the Metaphor of Human Rights" (2001) 42 Harv. Int'l L. J. 201.

${ }^{52}$ Cass supra note 16 at 162-167; and Alston, supra note 49 at 818-820; and Howse and Nicolaidis, ibid.
} 
seeking to change the legal system for their economic benefit. ${ }^{53}$ The WTO as a constitution will discipline and rule over governments.

Petersmann's framework demands that domestic states and institutions conform to a set of ideals that he considers desirable and universal. The market is considered the paramount institution, not because it generates growth most efficiently (like Jackson's argument), but rather because it is the sphere that best ensures personal autonomy and liberty. The WTO as a constitution provides the main tool for individuals to use to agitate against the intrusiveness of the state.

Petersmann wants to shift decision-making power and the power of changing institutional practice away from government towards the trade policy elite within the WTO. Thus, the main actors for social change in Petersmann's development framework are the trade elite who structure the global market and individuals who ensure the national governments do not interfere with individual liberty. Understanding how a liberal trade regime affects economic growth and distribution has a secondary role in Petersmann's framework - the liberalization of trade is an end goal in and of itself as a human rights value.

Petersmann wants to empower the individual to overcome the government because he assumes government will necessarily infringe upon the individual's interest. ${ }^{54}$ It is the trade policy elite that with their specialized knowledge and dedication to a liberal trade regime that will best structure the WTO in ways to optimally affect international and domestic law. Individuals, can then in turn pressure their own government towards economic liberty by invoking the constitutionalized WTO through domestic courts. ${ }^{55}$

As a development framework, Petersmann's notion of constitutionalism and the WTO does not provide instruction as to how people with competing values may interact amongst each other. It assumes that most individuals desire a state with a reduced regulatory role. In his focus on contesting the role of the state, Petersmann assumes that the role of law and legal institutions is to limit government action through individual action. Petersmann's implicit development framework also presupposes the state already has domestic legal institutions in place (courts, administrative tribunals, etc.) that an individual can effectively use to reduce the regulatory role of the government.

\section{CONCLUSION - IRONIC ROLES FOR MARKETS AND INSTITUTIONS}

\footnotetext{
${ }^{53}$ See "Multilevel Constitutionalism", supra note 42 at 44; and International Trade Law and GATT/WTO Dispute Settlement System, supra note 42 at 114-115.

54 "Multilevel Constitutionalism", ibid. at 26.

${ }^{55}$ Ibid. at 35 .
} 
Jackson's concept of the WTO emphasizes the institutional structure as a constitution yet considers the market to be the normatively paramount social institution based on the premise that the market generates growth most efficiently. Petersmann's constitutional argument, which focuses on economic rights and prioritizes the market, considers the WTO as a paramount institution to discipline national governments. The role of domestic institutions, according to Jackson, is to ameliorate the detrimental effects of free trade - despite Jackson's reserved confidence in the ability of domestic institutions to achieve this goal. Petersmann relies on domestic institutions as necessary to limit the role of government, and looks to the WTO to buttress these domestic institutions. The irony is that that Jackson's institutional functionalist conception of the WTO prioritizes the market, whereas Petersmann's economic functionalist conception of the WTO prioritizes the international trade institution.

Despite certain differences their remains commonalities in these implicit development frameworks. Both frameworks delineate an "economic sphere" that is separate from a "political sphere". They consider the "economic sphere" a place where actors shaped by the market, achieve the best welfare (however defined) for society and consider the "political sphere" as a place best avoided or limited. Also, both approaches prescribe a shift of decision-making power and the power of changing institutional practice away from government towards the trade policy elite within the WTO.

\section{DISPUTE SETTLEMENT}

\section{A. INTRODUCTION - METRICS OF LEGITIMACY}

The role of the dispute settlement system is a central concern in WTO legitimacy discussions. Members of the Appellate Body (AB) itself consider the issue of legitimacy merits consideration; ${ }^{56}$ some suggest that concern with WTO legitimacy may influence how disputesettlement decisions are made. ${ }^{57}$

\footnotetext{
${ }^{56}$ In reading the number of essays written by former AB members, WTO legal staff, and private counsel that appear before the WTO, there is an implicit purpose of needing to legitimate the dispute settlement system. See for e.g. Giorgo Sacerdoti, "Appeal and Judicial Review in International Arbitration and Ajudication: the Case of the WTO Appellate Review", in E-U Petersmann, ed., International Trade Law And The GATT/WTO Dispute Settlement System (1997) 247; Claus-Dieter Ehlermann "Six Years on the Bench of the "World Trade Court", in Frederico Ortino \& E-U Petersmann, eds., The WTO Dispute Settlement System 1995-2003 (2004) 499; Steve Charnovitz, Debra Steger \& Peter Van den Bossche eds., Law In The Service Of Human Dignity: Essays In Honour Of Florentino Feliciano (2005); and Rufus Yerxa and Bruce Wilson eds., Key Issues In WTO Dispute Settlement: The First Ten Years (2005).

${ }^{57}$ Robert Hudec, "GATT/WTO Constraints on National Regulation: Requiem for an 'Aim and Effects' Test (1998)", in Robert Hudec, Essays on the Nature of International Trade Law (1999) 359 at 375-376.
} 
The legitimacy of the WTO's dispute settlement system has primarily been measured against metrics of efficiency, efficacy and legality. Examinations of efficiency and efficacy are often made together and take-up a considerable amount of legal scholarship. Efficiency is measured by the least wasteful use of time and resources. Efficacy is measured by whether states comply with WTO rules or whether the WTO liberalizes trade. Compliance arguments propose ways in which member states can be pushed to adhere to WTO rules and the dispute settlement results. Tradeliberalization arguments suggest ways to use the dispute settlement mechanism to ensure that member states adopt appropriate economic policies.

Legality is measured by determining whether the law produced by the dispute settlement bodies is coherent and cohesive. The WTO dispute settlement is commonly understood to be a judicial entity despite formal monikers of "reports" and "appellate body" instead of decisions and courts. The dispute settlement system, and the $A B$ in particular, generate debates familiar to readers of legal scholarship, and especially to those who follow legitimacy debates concerning domestic courts. In this light, the $\mathrm{AB}$ is considered to be attempting to generate different legal doctrines to give itself, and therefore the WTO, increased legitimacy.

\section{B. The Development Debate - The Tension Between State and the WTO}

Arguments regarding the purpose of the dispute settlement system, the role of adjudicators, and method of interpretation characterize different notions of the relationship between the WTO and the state. Underlying all three measures of legitimacy is a concern with trying to resolve disputes in a manner that is legally consistent and coherent while maintaining the co-operation of participating countries. This tension has been characterized as one between the law of the WTO (the need for to resolve disputes in a coherent and cogent manner) and the politics of state negotiation and institutional adherence (the need for states to want to function under the auspices of and adhere to the WTO). Some suggest this tension is acute enough to contribute to the WTO's legitimacy crisis. ${ }^{58}$ Those who want a more politically informed dispute resolution system argue that state adherence is the most important factor to be addressed - if the Panels and $\mathrm{AB}$ do not take into account the ramifications of their decisions, states will either ignore the judicial decision, which weakens the WTO's legitimacy. Others argue that a rigorous legal analysis is more important because it establishes legitimacy by ensuring that the coherent structure of the WTO is maintained.

Indeed, some suggest that the relationship between international institutions and their member states is the central tension for all international institutions that has been theoretically unresolved

\footnotetext{
${ }^{58}$ Claus-Dieter Ehlermann, "Tensions Between The Dispute Settlement Process And The Diplomatic And TreatyMaking Activities Of The WTO" (2002) 3 World Trade Review 302.
} 
for decades. ${ }^{59}$ Rather than attempting to find the hypothetical golden mean between law and politics, I will show how unpacking the theories of the role of the dispute settlement system and reconstruing discussions as a development debate allows us to see how underlying normative assumptions regarding the WTO's function and purpose and the state's role in global governance shapes conceptions of dispute-settlement.

The different ways in which the three legitimacy metrics are used to overcome the perceived tension between law and politics is what distinguishes economic and institutional functionalist arguments. Economic functionalist arguments emphasize the economic benefits of the WTO and often use notions of legitimacy that focus on the ability of the dispute settlement system to discipline states to liberalize trade (efficiency and trade-liberalization efficacy). Institutional functionalist arguments emphasize the legality and institutional structure of the WTO by looking to theories of legitimacy that encourage the dispute settlement system to produce coherent legal doctrine alongside the need to ensure that states comply with WTO rules (efficiency, compliance efficacy, and legality).

Institutional functionalists will either call for more political considerations to inform disputeresolution or argue for the WTO adjudicator to find the balance between legal consistency and member state adherence. Accordingly, the role of the judge is central to the institution building of the WTO since her job is assumed to be about navigating the law in a legally coherent and cogent way that ensures state compliance and not just to "apply the law". The power of the judge stems from the (assumed) fact that Member States construct the WTO due to a willingness to cooperate. Since state's needs are a mix of the economic, social, political, etc., the judge is to find the right balance between all these needs of the state within the framework of the WTO. Within this approach, the trade dispute settlement is argued to be more effective the more countries participate and comply. All this stems from an assumption that that the role of the WTO is to manage the relationship between states on trade related matters. Regardless of whether the argument is for more politics or for balancing, this characterization of the WTO considers the role of the judge as a primary vehicle to mediate between law and politics through her interpretation.

Economic functionalist assume that the purpose of the WTO is to discipline governments to adhere to free trade principles. In this characterization of the WTO, governments know that in " 'tying their hands to the mast' (like Ulysses when he approached the island of the Sirens), reciprocal international pre-commitments [like the WTO] help them to resist the siren-like temptations from 'rent-seeking' interest groups at home. ${ }^{160}$ The WTO embodies a conception of a particular trade theory and its legitimacy is derived from the inherent benefits articulated by this theory. The judge derives her legal doctrine from this normative theory; her role is to sharpen doctrine towards achieving the benefits from this theory. Though country participation

\footnotetext{
${ }^{59}$ Klabbers, supra note 6.

${ }^{60}$ Petersmann, The GATT/WTO Dispute Settlement System; International Law, International Organizations and Dispute Settlement, supra note 42 at $36-37$.
} 
in the dispute system and the WTO is necessary, ultimate efficacy is measured in terms of how well the WTO acts to discipline governments towards liberal trade policies.

Considering that state compliance is necessary to any theory of dispute resolution legitimacy, empirical studies that measure use and adherence to the system are common. With regards to the consideration that developing countries do not use the dispute system to its full capacity, arguments are made to increase technical assistance for developing countries to use the dispute settlement system, which in turn would increase the dispute settlement system's legitimacy. Empirical studies can buttress both institutional and economic institutionalist arguments since the quantitative results do not in and of themselves address why countries should adhere and use the adjudication system.

The institutional functionalist emphasizes the role of the adjudicator as mediator and primarily determines legitimacy by measuring state participation. The economic functionalist emphasizes the role of the adjudicator as the implementer of WTO rules and determines legitimacy by measuring trade liberalization. This means that the economic functionalists place the WTO rules and institution as a paramount over the state, whereas the institutional functionalist considers the WTO rules and state interest as something to be balanced.

\begin{tabular}{|c|l|}
\hline Economic Functionalist & Institutional Functionalist \\
\hline WTO Law & \\
$\downarrow$ & WTO Law \\
Panel/Appellate Body & Body $\rightarrow \leftarrow$ State \\
State & \\
\hline
\end{tabular}

Box 4.1: Frameworks of the Role of Law and Adjudication

The different development frameworks can be further discerned from the different theories of law. According to economic functionalists, states created the WTO and comply with WTO law because of the expected welfare gains. States need the pressure of the dispute settlement system to overcome domestic obstacles blocking liberal trade policies. WTO adjudicators must thereby draw from a specialized knowledge of economics and use law as an instrument to implement the appropriate normative theory.

To economic functionalists, the perceived tension between WTO law and state politics is resolved by the expected welfare gains of liberal trade theory. This framework, however, by turning to economic theory does not necessarily resolve the tension. Economists debate whether a trade regime should reduce tariffs, reduce government involvement in the market, remove discrimination between domestic and foreign produced goods, increase competition, or combinations thereof, or all of the above. The economic functionalist approach is not informed by economic debate, rather it inherently mistrusts the state's capacity to determine and implement appropriate economic policy, and places the debate within an elite group of decisionmakers acting in an adjudicative capacity. 
The institutional functionalist's core concern, regardless of whether the argument is to ensure state adherence or legal coherence, is to preserve the WTO's institutional structure. The main focus is on the role of the judiciary to "balance" between the WTO trade rules (law) and the states' intents (politics). When some scholars think the judiciary is too isolated from the politics of state action they will argue for a more politically savvy judiciary that is attuned to states' needs to ensure their participation in the WTO. When the judiciary is considered too teleological, arguments for legal coherence are made to ensure the WTO's institutional integrity. Finding the point between law and politics, however, is predicated on assumption regarding the purpose of the WTO. If the purpose of the WTO is to ensure that states adhere to rules that liberalize trade, then an argument focused on doctrinal coherence is appropriate because the assumption would be that that coherent, cogent law will allow states to overcome power politics. This position, however, will always be vulnerable to a critique that that if the dispute settlement system remains focused only on doctrinal coherence and not on states' needs, states may not comply thereby reducing the integrity of the WTO. If the purpose of the WTO is act as a forum for states to negotiate, then an argument for a more politicized judiciary makes sense in order to ensure states' needs are met. In turn, this argument will always be vulnerable to the critique that the judiciary would then act as apologists for powerful states. In order to overcome this deadlock, a more productive approach would recognize the competing visions of the WTO's function and purpose and explicitly debate why the WTO or state should be the more important site of global governance.

\section{CONCLUSION}

Whether the role of the WTO adjudicator is imagined to be an institution-builder or trade

- technocrat, we can understand the legitimacy debate regarding. WTO dispute-resolution system as a discussion about the tension between the WTO and the state. Rather than attempting to "resolve" this tension, I have outlined how unpacking the respective theories regarding the role of adjudication shows the correlation between understandings of the dispute settlement system and development frameworks. 


\section{TRANSPARENCY AND PARTICIPATION ${ }^{61}$}

\section{A. INTRODUCTION}

Discussions regarding non-governmental participation and WTO transparency focuses on whether non-governmental actors (whether individuals, corporations, NGOs, civil society, or social movements) should concentrate their energy upon the state or the WTO. The debate is between those who are concerned with the legitimacy and capacity of the state to decide matters that have global effect (state-centric arguments of global governance) versus those concerned with the legitimacy and capacity of the WTO to decide matters that have global effect (institutional-centric arguments of global governance). These participation and transparency debates, like the dispute-settlement debate, can be understood to be about the relationship between the WTO and the state. Within the context of the dispute-settlement system, it is a matter of argument as to what the hierarchy should be between the WTO and the state. In the context of participation and transparency discussions, however, the starting assumption is that the WTO in fact dominates national policy-making capacity and the question is whether to encourage or ameliorate the effects of this supposed fact.

In this section, I first summarize how the terms of participation and transparency debate, when understood as a legitimacy debate, is between state-centric arguments versus institutional-centric arguments. I show that a state-centric argument correlates with an economic functionalist conception of the WTO and an institutional-centric argument correlates with an institutional functionalist conception.

I then examine how the debate shifted from before to after 1999 and show that there is no necessary correlation between an argument regarding participation and a particular development framework. I thereby argue that in order to understand the development implications of participation and transparency arguments we need to know more than whether someone is calling for increased participation or not. As such, this section provides the beginnings of how we might discern the development implications of this debate.

${ }^{61}$ The literature in this area is extensive. For a recent symposium on the topic see 11:4 J. Int'1 Econ. L. (2008). Other notable examples include Julio A. Lacarte, "Transparency, Public Debate, and Participation by NGOs in the WTO: a WTO Perspective, in Ernst-Ulrich Petersmann ed., Reforming the World Trade System: Legitimacy, Efficiency, and Democratic Governance 447 (2005); Robert Howse, "For A Citizen's Task Force on the Future of the World Trade Organization" (2004) 56 Rutgers L. Rev. 877; Steve Charnovitz, "Transparency \& Participation in the WTO" (2004) 56 Rutgers L. Rev. 927; Robert Wai, "Countering, Branding, Dealing: Using Economic and Social Rights in and Around the International Trade Regime" (2003)13 EJIL 35, 73-80; Steve Charnovitz, "WTO Cosmopolitics" (2002) 299 NYU J. Int'1 L. \& Pol. 299; Christophe Bellman \& Richard Gerster, "Accountability in the World Trade Organization" (1996) 30:6 J. of World Trade 32. 


\section{B. LEGITIMACY DEBATE}

\section{PRE-1999}

From the advent of the WTO, commentators debated the relationship between non-governmental actors and the WTO. At first, the focus was on inclusion of these actors, but after 1999 WTO transparency also became a prominent issue. Discussions regarding participation before 1999 did not consider non-governmental movements and organizations as potentially radical interventions questioning the legitimacy of the WTO. Rather, the starting premise was usually that the WTO is unquestionably a good thing because it embodies the ideas of "comparative advantage", leaving the debate regarding non-governmental participation to be about whether their inclusion will undermine the function and purpose of the WTO.

The central question was where should decisions that have global effect, matters of "global governance", be decided. Scholars were generally divided between those that were more statecentric and primarily concerned with strengthening the role of the state, wanting to leave all discussions of governance to domestic forums ${ }^{62}$ versus those that were institutional-centric who were confident in the legal personality, integrity, and robustness of the WTO to deal with global issues. $^{63}$

State-centric arguments characterized institutional-centric arguments as undermining state sovereignty and WTO functionality. The primary reasons for excluding non-governmental actors from the workings of the WTO were:

1) Opening up the WTO will distort the decision-making process and may lead to special interest capture. The purpose of achieving free trade will be undermined;

2) Non-governmental actors are not representative or electorally accountable. The appropriate democratic forum for these actors is their respective domestic government;

3) Northern non-governmental actors and issues will dominate Southern nongovernmental actors and issues; and

4) The WTO would be undermined due to the cacophony of voices muddling discussions between governments. Moreover, the WTO cannot fairly determine which nongovernmental actors should be in and which should be out.

\footnotetext{
${ }^{62}$ See for e.g. Philip M. Nichols, "Extension of Standing in World Trade Organization Disputes to Nongovernmental Parties” (1996) 17 U. Pa. J. Int'l Econ. L. 295.

${ }^{63}$ See for e.g. Daniel Esty, "Non-Governmental Organizations At The World Trade Organization: Cooperation, Competition, Or Exclusion" (1998) 1 J. Int. Econ. Law; Richard Shell, "The Trade Stake-Holders Model and Participation by Non-State Participants" (1996) 17 U. Pa. J. Int'l Econ. L. 359; Steve Charnovitz, "Participation of Nongovernmental Organizations in the World Trade Organization" (1996) 17 U. Pa. J. Int'l Econ. L. 331 (1996). But see JL Dunoff, "The Misguided Debate Over NGO Participation at the WTO" (1998) 1 J. Int. Econ. Law 443.
} 
Here the assumed function and purpose of the WTO is to ensure that international trade remains free according to economic theory - an economic functionalist understanding of the WTO.

Institutional-centric arguments characterized a state-centric approach as "anachronistic" in light of the interdependency of issues that can only be addressed on a global scale via international institutions. The institutional-centric scholars' confidence in the WTO stemmed from beliefs that the WTO was necessary, able to make domestic governments more democratic, and able to effectively address global issues - an institutional functionalist understanding of the WTO.

\section{Post-1999}

After 1999, the ideas and interests underlying the debate shifted and the arguments for transparency and participation increased and diversified. The issue of transparency is often linked with participation without any sharp distinctions between the two concepts. A large number of articles take the position that the WTO needs to be more transparent and allow for the participation of non-governmental actors. Scholars are not responding so much to state-centric critiques against non-governmental actor participation (even though arguments often include responses to some of those critiques). They are, instead, primarily reacting against the notion that in the days of the GATT, the trade regime operated like a "club" of a small number of likeminded relatively rich countries who negotiated in seclusion and made all the global trading rules. ${ }^{64}$ There is a general consensus that the "club model" is inherently illegitimate for its secrecy and elitism; the debate centers on legitimating the WTO through mechanisms of transparency and participation. Arguments for inclusion of non-governmental actors do not necessarily imply a desire to allow non-governmental actors to have any substantive influence on the function and purpose of the WTO. ${ }^{65}$ Reasons for increased transparency and participation include: substantively altering the WTO, ${ }^{66}$ educating the public about the benefits of free trade, participation and transparency, ${ }^{67}$ or domestically pressuring governments for increased transparency. ${ }^{68}$ The types of transparency prescribed also differs. They include what I call external transparency (how well do citizens and civil society have access to seeing how the WTO functions), internal transparency (are smaller and developing countries able to participate in the WTO and have access to negotiations and information), and regulatory transparency (how well

\footnotetext{
${ }^{64}$ Robert O. Keohane \& Joseph S. Nye Jr., "The Club Model of Multilateral Cooperation", in Roger B. Porter et al., eds., Efficiency, Equity, and Legitimacy: The Multilateral Trading System at the Millennium (2001) 264.

${ }^{65}$ Cf. Jeffrey L. Dunoff, "Civil Society at the WTO: The Illusion of Inclusion?" (2000) 7 ILSA J. Int'l \& Comp. L. 275 .

${ }^{66}$ See for e.g. James Gathii, "Process and Substance in WTO Reform" 29004) 56 Rutgers L. Rev. 885.

${ }^{67}$ See for e.g. Sungjoon Cho, "A Quest For WTO's Legitimacy” (2005), 4 World Trade Rev. 391.

${ }^{68}$ See for e.g. Sylvia Ostry, "WTO: Institutional Design For Better Governance", in Roger B. Porter et a.l, eds., Efficiency, Equity, And Legitimacy: The Multilateral Trading System At The Millennium 361 (2001); and Sylvia Ostry, The World Trade Organization: NGOs, New Bargaining Coalitions, and a System Under Stress (2006).
} 
does the WTO ensure national governments incorporate mechanisms of transparency as a central feature of domestic legal systems).

The state-centric view draws from an economic functionalist conception of the WTO and argues for non-governmental actors to get involved in order to discipline state action. Whereas the institutional-centric view draws from an institutional functionalist conception and argues for non-governmental actors to get involved in order to directly change the WTO. 


\section{CONCLUSION - SHIFT FROM DESIRE TO APPREHENSION}

I have summarized below in a table the pre- and post-1999 arguments regarding nongovernmental actor participation and WTO transparency.

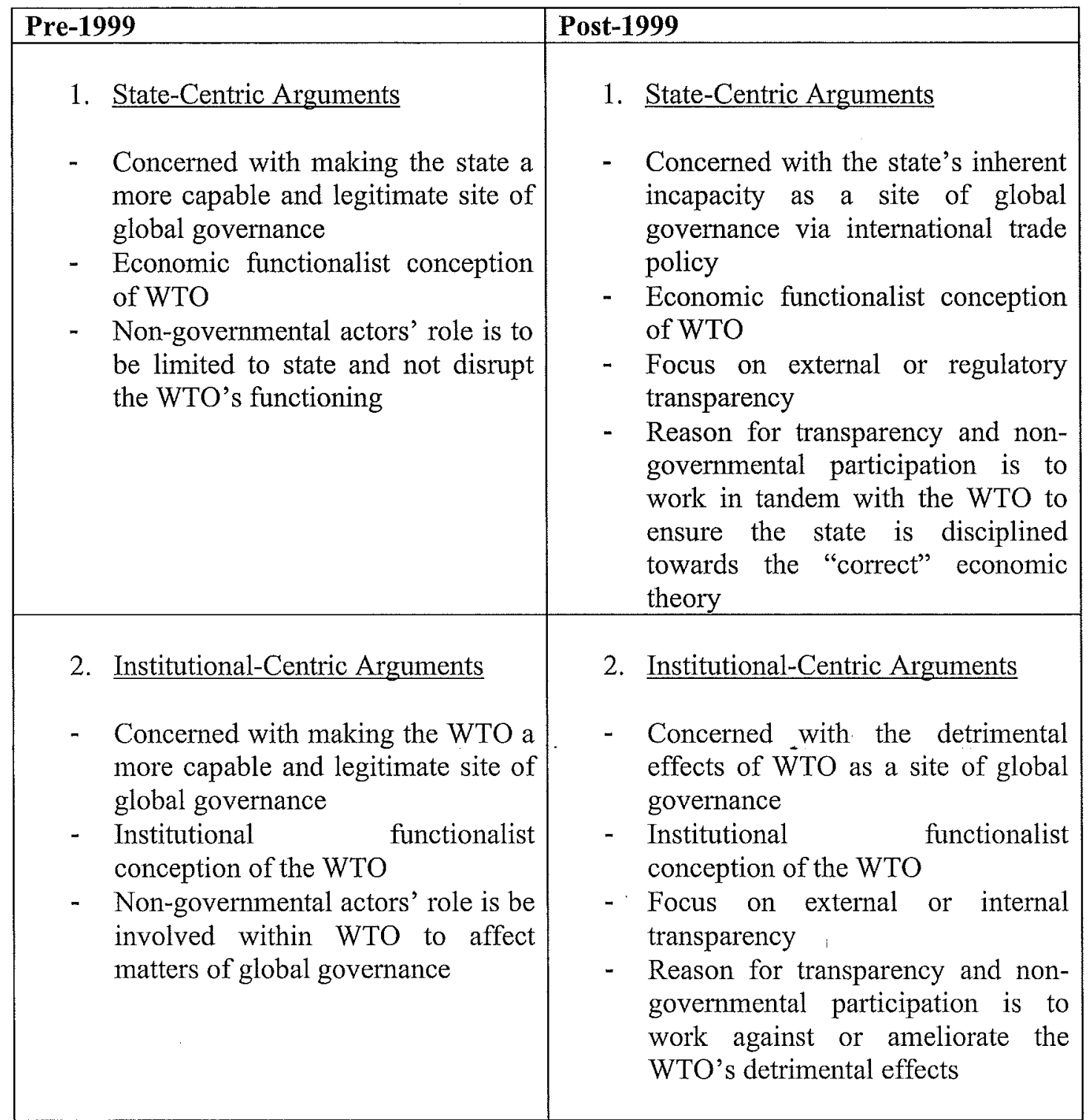

Table 5.1: Summary of participation and transparency arguments

There is a shift in why commentators focus discussion on the state. At first, the concern stemmed from a desire to make the state a strong site of global governance. After 1999, the concern for the 
state shifts to building upon the assumption that the state is inherently a weak site of global governance. A pre-1999 state-centric argument places non-governmental actors primarily in the domestic forum assuming that they can best support the WTO by not interfering with its operation. Post-1999, non-governmental actors are called upon to support the WTO, whether domestically or internationally, in disciplining the state. Regardless of the shifts in state-centric arguments, what remains consistent is an economic functionalist conception of the WTO. The corollary is that the assumed purpose for non-governmental actors remains consistent - they are to encourage the liberalization of trade. What differs are arguments as to where and how to achieve this goal.

Similarly, there is also a shift in why commentators focus discussion on the WTO. The concern begins as a desire to make the WTO a strong institution of global governance. After 1999, the concern with the WTO becomes a response to the assumption that the WTO is detrimental to some people's daily lives. The consistent dynamic underlying the shift is supposing that the WTO is an institution that has global effect and that non-governmental actors must therefore get involved to engage with this institution. The institutional functionalist conception of the function and purpose of the WTO remains the same between the two periods; what differs is whether the outlook towards the WTO's effects is optimistic or pessimistic. What also differs is that pre-1999 there is an ambiguity regarding the role of the state in global governance - the call for a more legitimate WTO can incorporate either support for the state or skepticism towards the state. After 1999, the assumption is that the state should and does matter with regards to everyday life, and in light of the effects of WTO upon the state, we must reconsider how should the state matter.

Looking more closely at Table 5.1, there is an ironic turn from pre- to post-1999 arguments revealing that prescribed roles for non-governmental actors do not necessarily stem from the same conceptions of the WTO. A call for increased non-governmental actor participation and WTO transparency can stem from either: 1) an institutional functionalist conception celebrating the WTO as a site of global governance that is ambivalent about the role of the state (pre-1999 institutional centric); or 2) an economic functionalist conception of the WTO that is skeptical of the state's role in matters of global governance (post-1999 state centric). Likewise, a consideration that non-governmental actors should not work within or alongside the WTO can stem from either: 1) an institutional functionalist conception that is worried about the WTO's effect on the role of the state in daily life, thereby supportive of non-governmental action that ameliorates the WTO's effect (post-1999 institutional centric); or 2) an economic functionalist conception of the WTO that is confident in its economic benefits and skeptical of nongovernmental participation beyond the state (pre-1999 state centric).

\section{CONCLUSION}

The unfortunate effect of the contestations and justifications of the WTO's legitimacy has been the obscuring of normative assumptions underpinning conceptions of the WTO. One suspects 
that the more the discourse continues in this tug-of-war of legitimacy, the more entangled our understanding of the WTO will be. Thus, by reconstruing the legitimacy debates towards a development debate, we gain a better sense of what conceptions of the WTO are dominating legal thought. What first emerges is that there are economic functionalist and institutional functionalist conception of the WTO's purpose. What is then discerned is that each conception corresponds to a particular development framework.

This article goes on to show that a particular conception of the WTO does not necessarily correspond to a particular development framework. The context of a the particular legitimacy debate determines how a conception of the WTO is linked to a particular development framework because each debate is examining a particular dynamic among the WTO, the market, non-governmental actors, and the state.

With these sharper analytical tools in mind, I suggest we engage in a more substantive and detailed debate as to what the function and purpose of the WTO should be rather than debate how to improve the WTO's legitimacy based on predicated conceptions of the WTO. This may allow for a more productive way of imagining the WTO as a development institution. 
